\title{
PENGOLAHAN LIMBAH CAIR KOSMETIK SECARA ELEKTROKOAGULASI SISTEM BATCH
}

\author{
Sutanto $^{1 *}$, Kareina Artanti ${ }^{1}$ \\ ${ }^{1}$ Program Studi Kimia FMIPA Universitas Pakuan, Bogor \\ *e-mail: sutanto@unpak.ac.id
}

diterima: 20 Juni 2019; direvisi:25 Juli 2019; disetujui:10 Agustus 2019

\begin{abstract}
ABSTRAK
Keberhasilan pengolahan limbah cair metoda elektrokoagulasi dipengaruhi oleh kerapatan voltase dan waktu kontak. Telah dilakukan penelitian pengolahan limbah cair warna kemerahan dari industri kosmetik dengan cara elektrokoagulasi sistem batch. Penelitian bertujuan untuk menentukan kondisi optimum kerapatan voltase dan waktu yang dapat hasil pengolahan limbah cair kosmetik yang efektif metoda elektrokoagulasi sistem batch. Sampel limbah cair kosmetik warna kemerahan diambil dari industri kosmetik dan dianalisis parameter mutu air limbah meliputi: pH; oksigen terlarut (DO); Kebutuhan Oksigen Kimia (COD) kadar logam Fe dan Al, dan selanjutnya dilakukan pengolahan limbah. Sebanyak $0,5 \mathrm{~L}$ sampel limbah dilakukan elektrokoagulasi sistem batch menggunakan wadah (chamber) kaca volume satu liter menggunakan elektroda pelat aluminium $1 \mathrm{~mm}$ ukuran $5 \mathrm{~cm}$ x $10 \mathrm{~cm}$ efektif tercelup, jarak antar elektroda $5 \mathrm{~cm}$. Kedua elektroda diberi tegangan listrik bervariasi : 9; 12; 15; dan 20 volt DC dan masing-masing dengan variasi waktu: 15; 30; 45; dan 60 menit, percobaan diulang dua kali. Air hasil elektrokoagulasi dianalisis sejumlah parameter mutu sesuai analisis awal. Pengolahan terbaik kondisi optimum menghasilkan mutu air : $\mathrm{pH}=9,96 ; \mathrm{DO}=6,9 \mathrm{mg} / \mathrm{L} ; \mathrm{COD}=$ $280 \mathrm{mg} / \mathrm{L}$ (penurunan 74,19\%); TSS $=88 \mathrm{mg} / \mathrm{L}$ (penurunan 86,21\%); $\mathrm{Fe}=0,31 \mathrm{mg} / \mathrm{L}$ (penurunan $\mathrm{Fe}$ 80,38\%). Hasil pengolahan elektrokoagulasi ini memenuhi baku mutu air limbah menurut Permen LH no 05 tahun 2014 lampiran XLVII golongan II kecuali pH $(>9,0)$., dan dapat dibuang badan air.
\end{abstract}

\section{Kata Kunci: Limbah cair kosmetik, elektrokoagulasi, kerapatan voltase \\ PROCESSING LIQUID WASTE COSMETICS ELECTROCOAGULATION SYSTEM BATCH}

\begin{abstract}
The success of this electrocoagulation method wastewater treatment is influenced by the voltage density and contact time. A reddish liquid waste treatment from the cosmetics industry has been carried out by batch electrocoagulation system. The research aims to determine the optimum voltage and time density conditions that can be the result of effective cosmetics liquid waste treatment by batch system electrocoagulation method. Reddish cosmetics liquid waste samples were taken from the cosmetics industry and analyzed the parameters of waste water quality including: $\mathrm{pH}$; dissolved oxygen (DO); Chemical Oxygen (COD) requirements for $\mathrm{Fe}$ and $\mathrm{Al}$ metal content, and then waste treatment is carried out. A total of 0.5 liters of waste samples were carried out by electrocoagulation of a batch system using a one liter volume glass chamber using $1 \mathrm{~mm}$ aluminum plate electrodes measuring $5 \mathrm{~cm} \times 10 \mathrm{~cm}$ effectively immersed, the distance between the electrodes was $5 \mathrm{~cm}$. Both electrodes were given varying electric voltages: 9; 12; 15; and 20 volts DC and each with time variations: 15; 30; 45; and 60 minutes, the experiment was repeated twice. Electrocoagulation water is analyzed a number of quality parameters according to the initial analysis. The best treatment optimum conditions produce water quality: $\mathrm{pH}=9.96 ; \mathrm{DO}=6.9 \mathrm{mg} / \mathrm{L} ; \mathrm{COD}=280 \mathrm{mg} / \mathrm{L}$ (a decrease of 74.19\%); $\mathrm{TSS}=$ $88 \mathrm{mg} / \mathrm{L}$ (a decrease of $86.21 \%$ ); Fe $=0.31 \mathrm{mg} / \mathrm{L}$ ( $80.38 \% \mathrm{Fe}$ decrease). The results of this electrocoagulation treatment meet wastewater quality standards according to Permen LH No. 05 of 2014 annex XLVII class II except pH (> 9.0)., And can be discharged by water bodies.
\end{abstract}

Keywords: Cosmetic liquid waste; electrocoagulation; voltage density 


\section{PENDAHULUAN}

Berdasarkan data Kementerian Perindustrian tahun 2016 pertumbuhan pasar industri selama 5 tahun terakhir mencapai $9,67 \%$, di dalamnya termasuk industri kosmetik. Dilihat dari penggunaannya kosmetik dibagi menjadi dua yaitu pertama, kosmetik untuk perawatan kulit (skin-care coasmetic), digunakan untuk memelihara, merawat, dan mempertahankan kondisi kulit. Kedua, kosmetik riasan (dekoratif atau make up) merupakan kosmetik yang digunakan untuk memperindah wajah. Dalam kosmetik riasan ini zat warna memegang peranan penting (Trianggono dkk, 2007).

Zat warna dalam kosmetik berasal dari berbagai sumber dan dikelompokan sebagai: zat warna alam yang larut; zat warna sintesis; dan pigmen-pigmen alam; dan pigmen-pigmen sintetis. Zat warna sintetic dibuat dari bahan kimia sepeti anilin, benzena, toluen, maupun antrasena. Pigmen alami seperti aluminium silikat, oksida besi atau manganoksida. Pigmen sinteisis seperti zinc oksida, titanium oksida sering digunakan untuk pewarna cosmetik. Lipstik adalah salah satu contoh produk kosmetik dekoratif. Bahan penyusun lipstik utamanya adalah lilin, minyak, zat pewarna, antioksida, bahan pengawet dan pewangi.

Limbah cair kosmetik berasal dari pencucian peralatan dengan menggunakan air dan sabun/deterjen. Dengan demikian limbah kosmetik dekoratif dapat mengandung lemak/minyak, zat warna, mineral logam dan deterjen, sehingga mutu limbah cair dimungkinkan memiliki nilai BOD COD dan TSS yang tinggi. Baku mutu air limbah industri kosmetik tidak diatur secara khusus dalam Peraturan Menteri Lingkungan Hidup, PermenLH no. 5 tahun 2014. Mengacu pada baku mutu limbah farmasi pada peraturan ini, $\mathrm{pH}=6-9 ; \mathrm{BOD}_{5}=100 \mathrm{mg} / \mathrm{L} ; \quad \mathrm{COD}=300$ $\mathrm{mg} / \mathrm{L} ; \mathrm{TSS}=100 \mathrm{mg} / \mathrm{L} ;$ Total $\mathrm{N}=30 \mathrm{mg} / \mathrm{L}$ dan Total fenol $=1 \mathrm{mg} / \mathrm{L}$. Namun demikian dalam regulasi ini bagi industri yang belum ditetapkan baku mutu air limbahnya dapat menggunakan baku mutu berdasarkan Lampiran XLVII permen tersebut. Mengacu pada lampiran ini untuk golongan II yang berkaitan erat dengan karakteristik limbah adalah: TDS $4000 \mathrm{mg} / \mathrm{L}$; $\mathrm{TSS}=400 \mathrm{mg} / \mathrm{L} ; \mathrm{pH}$ 6-9; $\mathrm{BOD}=150 \mathrm{mg} / \mathrm{L}$; $\mathrm{COD}=300 \mathrm{mg} / \mathrm{L}$; total fenol $=1 \mathrm{mg} / \mathrm{L}$ dan kadar $\mathrm{Fe}=10 \mathrm{mg} / \mathrm{L}$; lemak dan minyak $20 \mathrm{mg} / \mathrm{L}$, serta parameter umum lain kurang tidak secara spesifik berhubungan dengan limbah cair kosmetik.

Metoda pengolahan limbah cair secara elektrokoagulasi adalah metoda pengendapan dengan koagulan yang dibangkitkan secara listrik dengan mengorbankan elektroda. Metoda ini sederhana dan mudah diterapkan dengan kemampuan yang baik dalam menggumpalkan berbagai polutan organik maupun an organik (Harsanti, 2010), dan dapat menurunkan warna hingga 100\% (Chaturvedi, 2013) . Teknologi ini tidak memerlukan lahan yang luas dan tanpa memerlukan bahan kimia. Dengan demikian teknologi elektrokoagulasi $(\mathrm{EC}=$ Electro Coagulation) dapat menjadi alternatif pengolahan limbah kosmetik. Keberhasilan pengolahan ini dipengaruhi oleh kerapatan arus dan voltase yang diterapkan serta jenis limbah cair yang diolah.

Pada prinsipnya, metoda elektrokoagulasi menerapkan dua buah lempeng elektroda yang dimasukkan kedalam limbah cair yang diolah. Kedua elektroda dialiri arus searah $(\mathrm{DC}=$ direct current $)$ sehingga terjadi proses elektrokimia. Susunan rangkaian elektroda dapat diterapkan secara paralel monopolar atau bipolar dengan elektroda bantu. Selain dari itu arus bolak balik ( $\mathrm{AC}=$ alternating current $)$ juga dapat diterapkan (Yousuf A Mollah et al, 2001). Pada penerapan arus DC, reaksi yang terjadi pada anoda adalah oksidasi elektroda. Menurut Ali and Yaakob,(2012), reaksi dapat terjadi sebagai berikut:

Pada anode $\quad: \mathrm{Al} \rightarrow \mathrm{Al}^{3+}+3 \mathrm{e}^{-}$

Dalam kondisi alkaline terendapkan

$$
\mathrm{Al}^{3+}+3 \mathrm{OH}^{-} \rightarrow \mathrm{Al}(\mathrm{OH})_{3}
$$

Dalam kondisi asam terbentuk oksigen

$$
\begin{aligned}
\mathrm{Al}^{3+}+\mathrm{H}_{2} \mathrm{O} & \rightarrow \mathrm{Al}(\mathrm{OH})_{3}+3 \mathrm{H}^{+} \\
2 \mathrm{H}_{2} \mathrm{O} & \rightarrow \mathrm{O}_{2}+4 \mathrm{H}^{+}+4 \mathrm{e}^{-}
\end{aligned}
$$

Pada Katoda : $2 \mathrm{H}_{2} \mathrm{O}+2 \mathrm{e}-\rightarrow \mathrm{H}_{2}+2 \mathrm{OH}^{-}$

Dari reaksi tersebut bahwa selama elektrokoagulasi akan terbentuk ion $\mathrm{OH}^{-}$dan ion $\mathrm{H}^{+}$yang keduanya dapat saling menetralkan atau jika kuantitas keduanya tidak sama akan dapat mengubah $\mathrm{pH}$ larutan. Perubahan $\mathrm{pH}$ larutan dapat menyebabkan laju elektrokoagulasi berubah. Pada pH tinggi pada umumnya laju elektrokoagulasi meningkat (Vepsäläinen, 2012). Oleh karena itu pH awal limbah cair 
yang akan diolah secara elektrokoagulasi sangat penting diperhatikan.

Menurut Vepsäläinen (2012), mekanisme elektrokoagulasi secara skematik digambarkan sbb: Pada anoda pelat logam teroksidasi menghasilkan ion logam dan melepaskan elektron. Ion logam dapat berperan sebagai koagulan. Ion logam selanjutnya dapat mengalami hidrolisis menghasilkan ion logam hidroksida bermuatan yang bertindak sebagai flokulan. Dengan demikian polutan organik dapat mengalami koagulasi dan flokulasi. Pada Katoda, terbentuk gas $\mathrm{H}_{2}$ dan juga gas oksigen yang dapat mendorong flokulat mengapung keatas permukaan cairan.

Keberhasilan teknik elektrokoagulasi ditentukan oleh berbagai hal meliputi: jenis elektroda yang digunakan, jarak elektroda, waktu elektrokoagulasi; dan besarnya penerapan voltase dan arus listrik searah, serta jenis dan konsentrasi limbah cair yang diolah. Keberhasilan yang dimaksud pada umumnya dinyatakan dalam \% penyisihan parameter kebutuhan oksigen kimiawi $(\mathrm{COD}=$ chemical oxygen demand $)$, total padatan tersuspensi (TSS) dan warna jika limbah berwarna serta parameter pendukung lainnya.

Teknik elektrokoagulasi dapat menurunkan warna sampai $95 \%$ dengan kerapatan arus $31 \mathrm{~mA} / \mathrm{cm}$, waktu 4 jam . Pengolahan limbah oli dan grease dapat menghilangkan COD sampai 55,4 \%, menghilangkan $98,4 \%$ oli dan grease; menghilangkan TSS sampai $96,59 \%$ pada penerapan voltase 18,2 Volt dalam waktu 23,5 menit (Butler et.al., 2011). Kondisi terbaik untuk menurunkan zat warna limbah cair tekstil sarung samarinda yaitu penerapan listrik 9 volt dengan jarak elektroda $3 \mathrm{~cm}$ (kerapatan 3 volt $/ \mathrm{cm})$, waktu elektrokoagulasi 180 menit, dengan penghilangan COD mencapai 94,29\% (Irawan et. al., 2012). Menurut Bazrafsha et al., (2012), keberhasilan elektrokoagulasi ion fluorida dipengaruhi oleh jenis elektroda, konsentrasi awal ion fluorida, $\mathrm{pH}$ dan waktu elektrolisis. Penggunaan elektroda $\mathrm{Fe}$ pada limbah cair kelapa sawit
(LCPKS) terbaik pada jarak elektroda $5 \mathrm{~cm}$, pada voltase 5 volt dan kuat arus 5 amper dengan waktu 180 menit, dapat menurunkan COD $81,32 \%$ dan menurunkan turbiditas 95,08\% (Hanum et.al.,, 2015). Pada penelitian ini dilakukan elektrokoagulasi limbah cair kosmetik untuk mendapatkan kondisi optimum penerapan voltase (kerapatan voltase) dan waktu elektrokoagulasi pada jarak elektroda $5 \mathrm{~cm}$ untuk mendapatkan hasil yang efektif memenuhi baku mutu yang dipersyaratkan.

\section{BAHAN DAN METODE}

Penelitian dilakukan dalam dua tahap, pertama: pengambilan sampel dan analisis karakteristik sampel. kedua; percobaan penetapan kondisi optimum (voltase dan waktu) metoda elektrokoagulasi; Sampling dilakukan dengan metoda purposive sampling yaitu limbah cair kosmetik warna merah. Selanjutnya sampel dianalisis meliputi: $\mathrm{pH}$; DO (oksigennterlarut); COD; dan TSS (total padatan tersuspensi), kadar Fe dan kadar Al.

Percobaan pengolahan limbah cair kosmetik metoda elektrokoagulasi: Disiapkan 16 chamber (beaker glas) volume $1 \mathrm{~L}$. Kedalam masingmasing chamber diisi $500 \mathrm{~mL}$ limbah cair kosmetik. Kedalam chamber dimasukkan dua pelat elektroda aluminium masing-masing ukuran $5 \times 10 \mathrm{~cm}$ ditempatkan pada jarak $5 \mathrm{~cm}$, dan dialiri arus listrik searah dengan variasi tegangan: $9 ; 12 ; 15$ dan 20 volt, dengan waktu elektrolisis bervariasi : 15; 30; 45; dan 60 menit. Selanjutnya sampel dianalisis meliputi: $\mathrm{pH}$; DO (oksigennterlarut); COD; dan TSS (total padatan tersuspensi), kadar Fe dan kadar Al.

Seting peralatan elektrokoagulasi adalah sebagai berikut: 


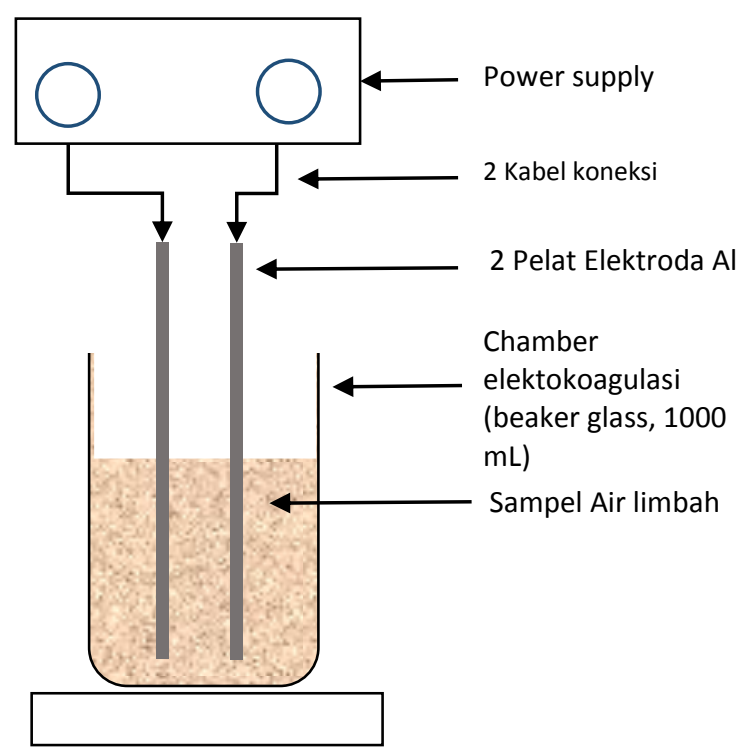

Gambar 1. Skema peralatan penelitian elektrokoagulasi

Prosedur analisis parameter air

a. Pengukuran pH: mengacu SNI 066989.11.2004. Dilakukan kalibrasi $\mathrm{pH}$ meter dengan buffer 7, kemudian 4 dan 10, sampai pH meter siap. Elektroda dicelupkan kedalam sampel dan dicatat penunjukan $\mathrm{pH}$.

b. Pengukuran oksigen terlarut (DO), dengan DO-meterdigital. Kalibrasi DO meter dilakukan dengan membiarkan probe diudara hingga pembacaan stabil lalu ditekan tombol CAL/Esc. Sampel limbah dimasukkan dalam beaker glas $100 \mathrm{~mL}$. Probe DO meter dicelupkan kedalam sampel hingga pembacaan stabil, dan dicatat.

c. Kadar COD: mengacu pada SNI 6989.2.2009. Dipipet $5 \mathrm{~mL}$ sampel kedalam labu refluks, ditambahkan larutan digestion yang berisi $\mathrm{K}_{2} \mathrm{Cr}_{2} \mathrm{O}_{7} ; \mathrm{H}_{2} \mathrm{SO}_{4}$ pekat dan $\mathrm{HgSO}_{4}$ sebanyak 3 mL. Kemudian ditambahkan larutan pereaksi asam sulfat sebanyak $7 \mathrm{~mL}$ yang berisi $\mathrm{Ag}_{2} \mathrm{SO}_{4}$ dan $\mathrm{H}_{2} \mathrm{SO}_{4}$ pekat. Selanjutnya dilakukan refluks selama 2 jam diatas pemanas pada suhu $150^{\circ} \mathrm{C}$. Sampel hasil refluks didinginkan, kemudian diukur absorbansinya pada panjang gelombang $600 \mathrm{~nm}$. Larutan deret standar dibuat $0 ; 50 ; 100 ; 150$; dan $200 \mathrm{mg}$ $\mathrm{O}_{2} / \mathrm{L}$, dari larutan induk Kalium Hidrogen Ptalat (KHP), 425 mgKHP setara dengan 500 mg $\mathrm{O}_{2} / \mathrm{L}$. Dibuat kurva standart dan ditemukan persamaan regresi linier: $\mathrm{Y}=\mathrm{aX}$ $+\mathrm{b}$.
Rumus perhitungan: $C O D=$ $\frac{y-b}{a} \times f p \quad m g O_{2} / L$

c. Kadar total padatan tersuspensi (TSS). Mengacu pada SNI 06-6989.3.2004. Sebanyal $50 \mathrm{~mL}$ sampel dimasukkan kedalam gelas piala $100 \mathrm{~mL}$, kemudian disaring dengan kertas saring no 41 . Selanjutnya kertas saring dikeringkan selama 1 jam pada $105^{\circ} \mathrm{C}$, didinginkan dalam desikator, kemudian ditimbang. Dihitung kadar TSS dengan rumus:

$$
\begin{aligned}
& \text { TSS }\left(\frac{m g}{L}\right)=\frac{(A-B) \times 1000}{\text { Volume sampel }(m L)} \\
& \mathrm{A}=\text { berat kertas saring + residu } \\
& \mathrm{B}=\text { Berat kertas saring }
\end{aligned}
$$

d. Penetapan Kadar Fe. Mengacu pada SNI 6869.4.2009. spektrofotometri serapan atom. Dibuat deret standar Fe : 0,5 ppm; 1 ppm; 1,5 ppm; dan 2 ppm masing masing $100 \mathrm{~mL}$ dari larutan induk 1000 ppm. Sebanyak $50 \mathrm{ml}$ sampel disiapkan disaring dengan kertas saring no 41, $\begin{array}{lllll}\text { kemudian ditambahkan } 2 & \mathrm{~mL} & \mathrm{HNO}_{3}\end{array}$ pekat. Larutan deret standar dan larutan sampel diukur serapannya pada panjang gelombang 243,8 $\mathrm{nm}$ pada alat AAS dengan gas pembakar udara-asetilen. Serapan larutan deret standart (Y) dialurkan terhadap konsentrasinya (X) untuk mendapatkan persamaan regresi linier, $Y=a X+b$, dan digunakan untuk menghitung konsentrasi sampel. Perhitungan dilakukan dengan rumus:

$$
\text { Kadar } F e=X=\frac{Y-b}{a} \mathrm{mg} / \mathrm{L}
$$

e. Penetapan Kadar Al. Mengacu pada SNI 6989.34.2005. Dibuat deret larutan standar Al: 1 ppm; 2 ppm; 3 ppm; 4 ppm dan 5 ppm masing-masing sebanyak 100 $\mathrm{mL}$ dari larutan induk $1000 \mathrm{ppm}$. Disiapkan $50 \mathrm{~mL}$ sampel disaring dengan kertas saring no 41 dan ditambahkan 2 $\mathrm{mL} \mathrm{HNO}_{3}$ p. Larutan deret standar dan sampel diukur serapannya pada panjang gelombang $309,3 \mathrm{~nm}$ dengan alat AAS menggunakan gas pembakar $\mathrm{N}_{2} \mathrm{O}$ asetilen. Selanjutnya dibuat kurva standar dan ditemukan persamaan 
lilniernya $\mathrm{Y}=\mathrm{ax}+\mathrm{b} ; \mathrm{Y}=\mathrm{m}$ absorban; $\mathrm{a}$ kemiringan kurva; $\mathrm{x}=$ konsentrasi; dan $\mathrm{b}=$ intersep. Kadar Al dihitung berdasarkan persamaan deret standar sebagaimana perhitungan kadar $\mathrm{Al}$ tersebut.

$$
\text { Kadar } A l=X=\frac{Y-b}{a} \mathrm{mg} / L
$$

\section{Pengolahan Data}

Hasil analisis air setelah elektrokoagulsi: $\mathrm{pH}$; DO; COD; TSS; kadar Fe dan Kadar Al dialurkan terhadap waktu kontak elektrokoagulasi. Selanjutnya dievaluasi terhadap baku mutu menurut Permen LH no 5 tahun 2014 lampiran VXVII golongan II. Selanjutnya ditentukan kondisi terbaik yang efektif memenuhi baku mutu.

\section{HASIL DAN PEMBAHASAN}

\section{A. Karakteristik Limbah Cair Kosmetik}

Hasil analisis mutu limbah cair kosmetik disajikan pada Tabel 1. Sampel Limbah cair kosmetik bersifat agak basa, oksigen terlarut rendah dan kadar COD dan TSS sangat tinggi dibandingkan dengan baku mutu.

Tabel 1. Karakteristik sampel Limbah cair kosmetik

\begin{tabular}{|c|c|c|c|c|c|}
\hline \multirow{2}{*}{ No } & \multirow{2}{*}{ Parameter } & \multirow{2}{*}{ Satuan } & \multirow{2}{*}{$\begin{array}{c}\text { Hasil } \\
\text { analisis }\end{array}$} & \multicolumn{2}{|c|}{ Baku mutu* } \\
\hline & & & & Gol I & Gol II \\
\hline 1. & $\mathrm{pH}$ & - & 9,02 & $6,0-9,0$ & $6,0-9,0$ \\
\hline 2. & DO & $\mathrm{mg} / \mathrm{L}$ & 2,4 & - & - \\
\hline 3. & COD & $\mathrm{mg} / \mathrm{L}$ & 1085 & 100 & 300 \\
\hline 4. & TSS & $\mathrm{mg} / \mathrm{L}$ & 512 & 200 & 400 \\
\hline 5. & Fe terlarut & $\mathrm{mg} / \mathrm{L}$ & 1,58 & 5 & 10 \\
\hline 6. & Al terlarut & $\mathrm{mg} / \mathrm{L}$ & 0,02 & - & - \\
\hline
\end{tabular}

*Permen LH no 5 tahun 2014 Lampiran XLVII tanda - artinya tidak dipersyaratkan

Rendahnya DO berhubungan dengan tingginya kadar COD, merepresentasikan tingginya polutan organik dalam sampel. Tingginya kadar TSS mengakibatkan sampel nampak keruh, dan sampel nampak berwarna kuning kemerahan dapat disebabkan oleh adanya zat warna dan kadar besi terlarut.

\section{B. Hasil Pengolahan limbah Cair Kosmetik Secara Elektrokoagulasi \\ a. Hubungan pH terhadap Waktu Kontak}

Hasil rata-rata dari dua kali ulangan percobaan elektrokoagulasi pada berbagai kerapatan voltase disajikan dengan grafik seperti pada Gambar 2. Perubahan $\mathrm{pH}$ meningkat seiring dengan waktu dan kerapatan voltase secara tidak signifikan. Meningkatnya $\mathrm{pH}$ disebabkan reaksi yang terjadi pada katoda: $2 \mathrm{H}_{2} \mathrm{O}+2 \mathrm{e}-\rightarrow \mathrm{H}_{2}+2 \mathrm{OH}^{-}$(Ali and Yaakob,2012). lebih dominan dibandingkan dengan oksidasi air menjadai oksigen: $2 \mathrm{H}_{2} \mathrm{O} \rightarrow$ $\mathrm{O}_{2}+4 \mathrm{H}^{+}+4 \mathrm{e}^{-}$pada anoda. Semakin besar voltase diterapkan kekuatan arus relatif dapat meningkat sehingga intensitas elektrolisis meningkat, jumlah ion $\mathrm{OH}$ - terbentuk semakin banyak, dan $\mathrm{pH}$ semakin tinggi. Gambar 1 memperlihatkan pola perubahan $\mathrm{pH}$ selama elektrokoagulasi limnbah cair kosmetik pada berbagai penerapan voltase terhadap 2 elektroda $\mathrm{Al}$ yang berjarak tetap, $5 \mathrm{~cm}$.

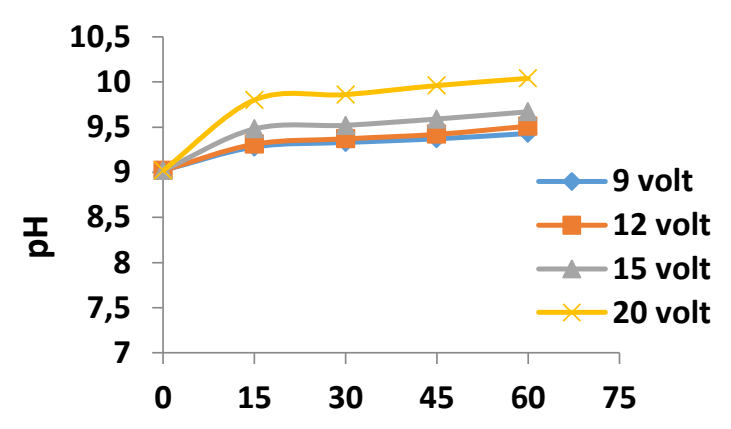

Waktu kontak elektrokoagulasi (menit)

Gambar 2. Hubungan $\mathrm{pH}$ terhadap waktu kontak elektrokoagulasi

Kerapatan voltase dihitung dengan membagi voltase dengan jarak sehinga pada masing-masing penerapan voltase memeiliki kerapatan $9 \mathrm{volt} / 5 \mathrm{~cm}(1,8 \mathrm{volt} / \mathrm{cm}) ; 12$ volt $/ 5 \mathrm{~cm}(2,4$ volt $/ \mathrm{cm}) ; 15$ volt $/ 5 \mathrm{~cm}$ (3 volt $/ \mathrm{cm})$; dan 20 volt $/ 5 \mathrm{~cm}(4 \mathrm{volt} / \mathrm{cm})$. Pada kerapatan voltase $4 \mathrm{volt} / \mathrm{cm}$ terjadi kenaikan $\mathrm{pH}$ yang paling tinggi, hal ini disebabkan intensitas elektrolisis paling tinggi, karena kerapatan voltase tinggi akan menaikkan 
kerapatan arus juga pada nilai daya hantar listrik yang sama.

Batasan pH air limbah yang boleh dibuang ke badan air adalah antara $\mathrm{pH} 6$ sampai 9 (Permen LH, no 5 tahun 2014). Hasil olahan limbah cair kosmetik ini mencapai $\mathrm{pH}>9$ untuk seluruh variasi penerapan voltase. Hal ini disebabkan karakteristik limbah cair kosmetik awalnya sudah memiliki pH 9. Untuk itu diperlukan upaya menurunkan $\mathrm{pH}$ air hasil pengolahan limbah cair atau perlu mengkodisikan $\mathrm{pH}$ air limbah sebelum dilakukan elektrokoagulasi dengan cara penambahan asam sulfat sejumlah yang diperlukan agar $\mathrm{pH}$ air hasil elektrokoagulasi berada pada batas-batas baku mutu yang berlaku.

\section{b. Hubungan DO terhadap waktu kontak}

Rata-rata hasil pengukuran kadar oksigen selama elektrokoagulasi limbah cair kosmetik disajikan pada Tabel 2, dan pola perubahan kadar DO diilustrasikan pada Gambar 3. Meskipun nilai DO tidak dipersyaratkan dalam baku mutu limbah tetapi DO dapat merepresentasikan jumlah polutan organik dalam air. Oksigen dalam air sangat diperlukan bagi kehidupan dalam air (hewan dan tanaman air). Tidak akan ada kehidupan dalam air tanpa oksigen. Dalam kondisi normal, air jernih pada suhu $25{ }^{\circ} \mathrm{C}$ dan tekanan 1 atmosfir, air mengandung oksigen 8,32 mg/L (Manahan, 2005). Jika terdapat polutan organik dalam air yang dapat dirombak oleh mikroba, maka proses perombakan ini akan mengkonsumsi oksigen sehingga kadar oksigen terlarut semakin menurun. Kelarutan oksigen minimal untuk mempertahankan kehidupan dalam air tergantung kepada suhu. Pada suhu 27,5 ${ }^{\circ} \mathrm{C}$ kebutuhan oksigen terlarut minhimal adalah 5,8 $\mathrm{mg} / \mathrm{L}$ (Connel \& Millder, 1995). Berdasarkan hal ini maka penerapan voltase 15 volt dan 20 volt, yaitu masing-masing memiliki kerapatan voltase 3 dan 4 volt $/ \mathrm{cm}$ dengan waktu 45 menit, pengolahan limbah cair kosmetik dapat memenuhi harapan karena air hasil olahan telah mencapai lebih dari kebutuhan oksigen terlarut minimal dalam air untuk kehidupan air.

Tabel 2. Hasil rata-rata pengukuran DO terhadap waktu kontak

\begin{tabular}{ccccccc}
\hline \multirow{2}{*}{$\begin{array}{c}\text { Voltase } \\
(\text { volt })\end{array}$} & $\begin{array}{c}\text { Kerapatan Voltase } \\
(\text { volt/cm) }\end{array}$ & \multicolumn{5}{c}{ Kadar Oksigen terlarut, DO (mg/L) } \\
\cline { 3 - 7 } & 0 menit & 15 menit & 30 menit & 45 menit & 60 menit \\
\hline 9 & 1,8 & 2,4 & 2,7 & 3,9 & 4,6 & 5,4 \\
12 & 2,4 & 2.4 & 3,8 & 4,3 & 4,8 & 5,3 \\
15 & 3,0 & 2,4 & 4,3 & 5,2 & 5,7 & 6,1 \\
20 & 4,0 & 2,4 & 4,4 & 5,9 & 6,9 & 6,7 \\
\hline
\end{tabular}

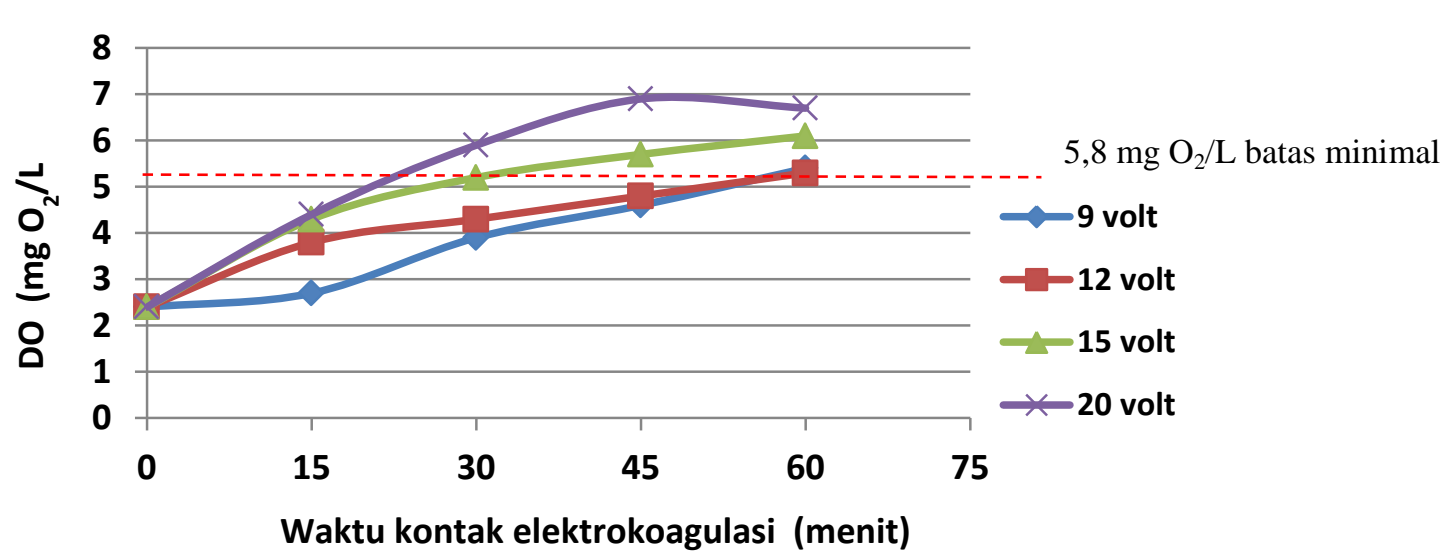

Gambar 3. Hubungan antara DO limbah cair kosmetik dan waktu kontak

Meningkatnya kadar oksigen terlarut (DO) disebabkan oleh reaksi oksidasi air menghasilkan $\mathrm{O}_{2}$. Reaksi pada anoda terjadi $2 \mathrm{H}_{2} \mathrm{O} \rightarrow \mathrm{O}_{2}+4 \mathrm{H}^{+}+4 \mathrm{e}^{-} \quad$ (Ali and 
Yaakob,2012). Selain dari pada itu jumlah polutan organik berkurang selama elektrokoagulasi sehingga oksigen dapat terlarut lebih banyak. Peningkatan DO optimal pada penerapan voltase 15 dan 20 volt selama $>45$ menit dapat mencapai $>5,8 \mathrm{mg} / \mathrm{L}$.

Penerapan listrik 20 volt menghasilkan nilai DO > 5,8 $\mathrm{mg} \mathrm{O}_{2} / \mathrm{L}$ pada 30 menit, dan terus meningkat hingga menit ke 45 mencapai maksimum $6,9 \mathrm{mg} / \mathrm{L}$, tetapi menurun pada menit ke 60. Penurunan ini dapat terjadi akibat perubahan menurunnya daya hantar listrik larutan sehingga menurunkan arus anodik dan menyebabkan intensitas elektrolisis menurun. Pembentukan $\mathrm{O}_{2}$ dalam larutan disebabkan oleh proses oksidasi air pada anoda akibat elektrolisis. Kuantitas hasil elektrolisis salah satunya ditentukan oleh jumlah listrik yang dapat ditrasfer dalam larutan dari anoda ke katoda

\section{c. Hubungan COD terhadap waktu kontak}

Nilai COD merepresentasikan kandungan senyawa organik dalam air yang dapat dikosidasikan secara kimia. Semakin tinggi nilai COD berarti semakin buruk kualitas air. Baku mut air limbah hasil olahan limbah cair kosmetik untuk COD maksimum 300 mg/L (Permen LH no 5 tahun 2014). Tabel 3 menyajikan data pengamatan rata-rata nilai COD selama elektrokoagulasi pada berbagai penerapan voltase. Nilai COD nampak turun secara signifikan dari 1085 $\mathrm{mg} / \mathrm{L}$ menjadi terendah $192 \mathrm{mg} / \mathrm{L}$, yaitu mencapai 82,30 \%. Ghalwa et al (2016) dapat menurunkan COD limbah cair zat warna mencapai 83,3 \% tetapi dengan menerapkan arus yang tinggi. Percobaan Setianingrum dkk ( 2017) pada limbah zat warna penurunan COD mencapai $87 \%$ pada menit ke 60 pada tegangan listrik 15 volt dan jarak antar elektrode sebesar $2 \mathrm{~cm}$.

Penurunan COD disebabkan polutan organik teroksidasi dan sebagian terflokulasi sehingga memisah dari air. Semakin tinggi penerapan voltase dapat menurunkan COD cukup untuk mencapai baku mutu, khususnya pada penerapan voltase 15 dan 20 volt. Dengan demikian penerapan voltase optimal terjadi pada penerapan 15 volt, yaitu kerapatam voltas $15 \mathrm{vol} / 5 \mathrm{~cm}=3$ volt $/ \mathrm{cm}$.

Tabel 3. Hasil rata-rata analisis COD $(\mathrm{mg} / \mathrm{L})$ pada berbagai waktu kontak dan voltase

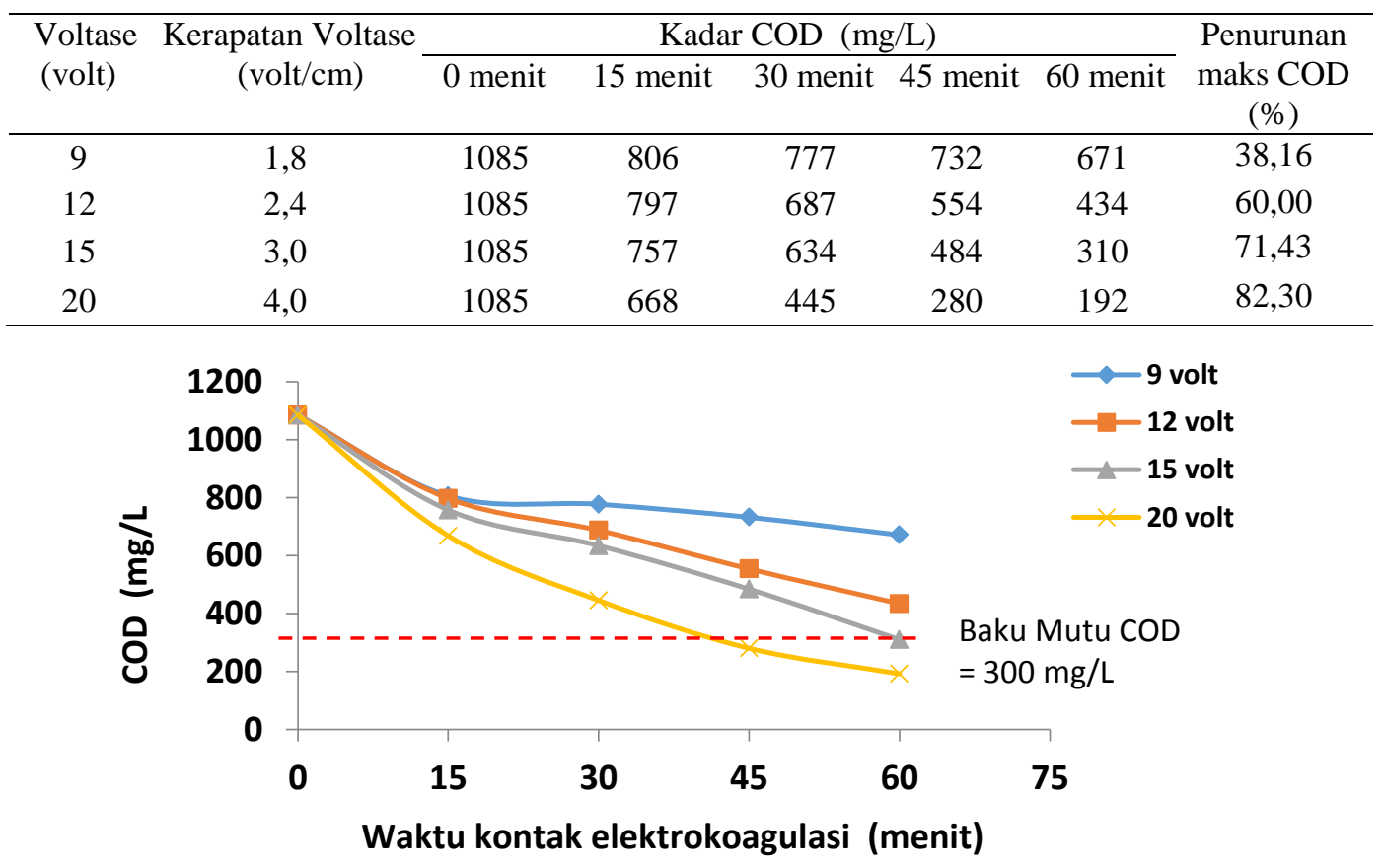

Gambar 4. Grafik hubungan antara COD dengan waktu kontak 



\section{d. Hubungan TSS terhadap waktu kontak}

Padatan tersuspensi $(\mathrm{TSS}=$ total suspended solid) dalam air limbah mencerminkan kandungan polutan organik dan anorganik yang dapat diendapkan dan atau disaring. Kadar TSS yang tinggi menyebabkan air nampak keruh. Hasil pengolahan limbah cair tekstile secara elektrokoagulasi sebagaimana disajikan pada Tabel 4, menunjukkan bahwa penerapan voltase yang semakin tinggi dapat menurunkan TSS lebih banyak, dari 512,4 mg/L menjdai 62,6 $\mathrm{mg} / \mathrm{L}$, yaitu mencapai $87,78 \%$. Penelitian elektrokoagulasi air limbah perkotaan pada penerapan 10 volt jarak elektroda $2 \mathrm{~cm}$ selama 25 menit dapat menurunkan TSS sebesar 61,38 $\%$ (Alex, 2015), dan elektrokoagulasi limbah industri pangan dengan 24 volt selama 60 menit dapat menurunkan TSS sampai 88,02\% (Gameissa et al, 2012). Penerapan voltase dan durasi lamanya waktu elektrokoagulasi menentukan besarnya penurunan TSS. Mempertimbangkan Baku mutu TSS menurut permen LH no 5 tahun 2014 adalah hanya 400 $\mathrm{mg} / \mathrm{L}$, sehingga perlakukan elektrokoagulasi pada berbagai penerapan voltase efektif menurunkan TSS pada 45 menit.

Gambar 5 mengilustrasikan perbedaan penurunan kadar TSS. Penurunan TSS cukup baik dan mengasilkan kadar yang memenuhi baku mutu pada penerapan 12 volt sampai 20 volt. Semakin tinggi penerapan voltase semakin besar dapat menurunkan nilai TSS, hal ini berkaitan dengan semakin tinggi voltase semakin tinggi pula kerapatan arus relatif elektrokoagulasi yang semakin besar.

Tabel 4. Hasil rata-rata analisis TSS ( $\mathrm{mg} / \mathrm{L}$ ) pada berbagai waktu kontak dan voltase

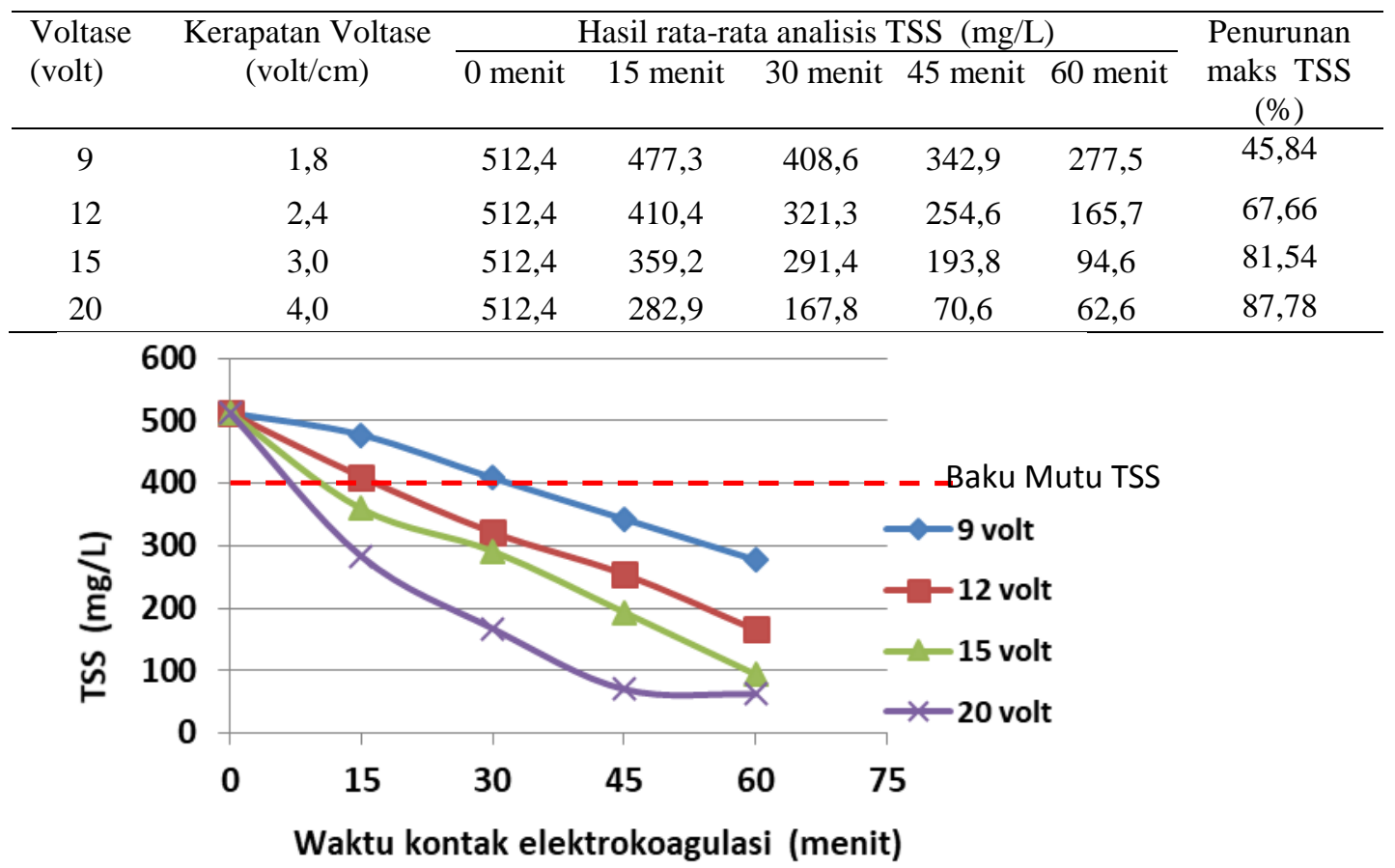

Gambar 5. Grafik hubungan TSS terhadap waktu kontak elektrokoagulasi

\section{e. Hubungan Kadar Fe terlarut terhadap waktu kontak}

Kadar Fe maksimum diperbolehkan menurut regulasi dalam limbah cair kosmetik adalah $10 \mathrm{mg} / \mathrm{L}$. Hasil analisis awal limbah cair kosmetik adalah 1,58 $\mathrm{mg} / \mathrm{L}$, yang berarti telah memenuhi baku mutu. Proses elektrokoagulasi dapat menurunkan maksimum hingga mencapai
$0,12 \mathrm{mg} / \mathrm{L}(92,40 \%)$ pada 20 volt selama 60 menit (Tabel 5). Penurunan ini disebabkan terjadinya penetralan ion $\mathrm{Fe}$ dalam larutan dan terflokulasi bersama polutan lainnya.

Satu molekul Ion besi III berikatan secara kovalen koordinasi dengan 6 molekul air membentuk ion kompleks $[\mathrm{Fe}$ $\left.\left(\mathrm{H}_{2} \mathrm{O}\right)_{6}\right]^{3+}$. Selama elektrokoagulasi 
berlangsung, $\mathrm{pH}$ larutan semakin meningkat (Gambar 2). Ion kompleks besi III dapat berubah, mengalami hidroksilasi berdasarkan reaksi sebagai berikut (Marriaga dan Martinez, 2014)
$\left[\mathrm{Fe}\left(\mathrm{H}_{2} \mathrm{O}\right)_{6}\right]^{3+}+\mathrm{OH}-\rightarrow\left[\mathrm{Fe}\left(\mathrm{H}_{2} \mathrm{O}\right)_{4}(\mathrm{OH})_{2}\right]$

$+{ }^{+}+\mathrm{H}_{2} \mathrm{O}$

$\left[\mathrm{Fe}\left(\mathrm{H}_{2} \mathrm{O}\right)_{4}(\mathrm{OH})_{2}\right]^{+}+\mathrm{OH}^{-}$

$\rightarrow\left[\mathrm{Fe}\left(\mathrm{H}_{2} \mathrm{O}\right)_{4}(\mathrm{OH})_{3}\right]_{(\mathrm{s})}+\mathrm{H}_{2} \mathrm{O}$

Tabel 5. Hasil rata-rata analisis Fe terlarut $(\mathrm{mg} / \mathrm{L})$ pada berbagai waktu kontak

\begin{tabular}{cccccccc}
\hline \multirow{2}{*}{$\begin{array}{c}\text { Voltase } \\
\text { (volt) }\end{array}$} & $\begin{array}{c}\text { Kerapatan Voltase } \\
\text { (volt/cm) }\end{array}$ & \multicolumn{5}{c}{ Rata-rata kadar Fe terlarut $(\mathrm{mg} / \mathrm{L})$} & Penurunan maks \\
\cline { 3 - 6 } & 0 menit & 15 menit & 30 menit & 45 menit & 60 menit & [Fe] (\%) \\
\hline 9 & 1,8 & 1,58 & 1,26 & 1,02 & 0,87 & 0,44 & 72,15 \\
12 & 2,4 & 1,58 & 1,14 & 0,83 & 0,57 & 0,26 & 83,54 \\
15 & 3,0 & 1,58 & 0,97 & 0,72 & 0,43 & 0,19 & 87,97 \\
20 & 4,0 & 1,58 & 0,95 & 0,65 & 0,31 & 0,12 & 92,40 \\
\hline
\end{tabular}

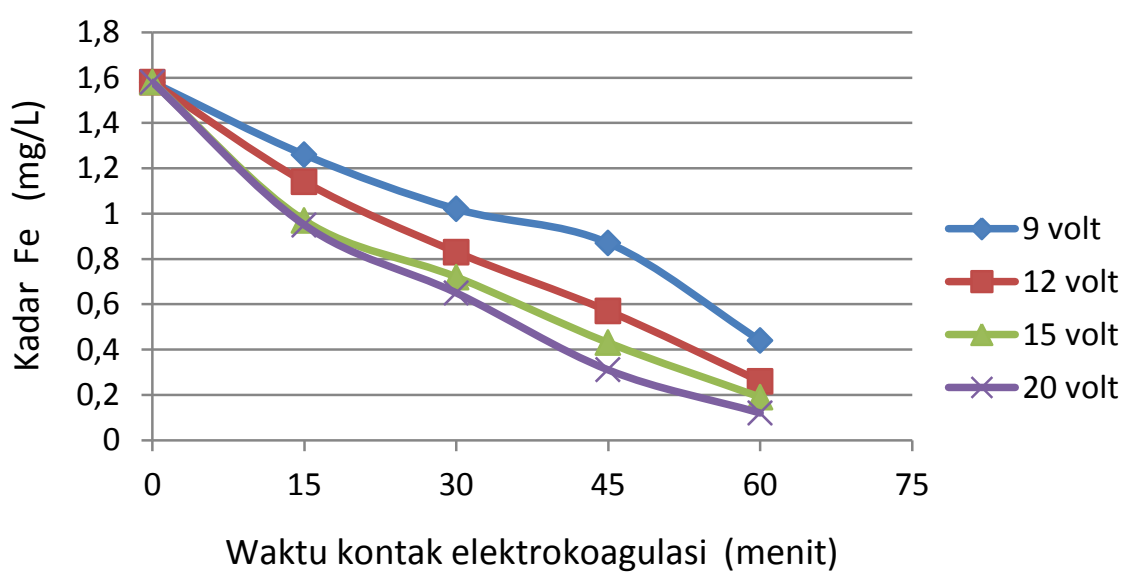

Gambar 6. Grafik hubungan kadar Fe dengan waktu kontak elektrokoagulasi

\section{f. Hubungan Kadar Al terlarut terhadap waktu kontak}

Kadar Al terlarut dalam air hasil olahan elektrokoagulasi berasal dari reaksi oksidasi elektroda $\mathrm{Al}$ selama elektrokoagulasi berlangsung. Anoda logam Al teroksidasi menjadi ion $\mathrm{Al}^{3+}$ selanjutnya membentuk koagulan. Selama proses koagulasi terjadi peningkatan $\mathrm{pH}$ larutan yang dapat menyebabkan kadar $\mathrm{Al}$ terlarrut semakin tinggi. Tabel 6 menyajikan data kadar $\mathrm{Al}$ terlarut selama elektrokoagulasi pada berbagai penerapan voltase dan waktu kontak, dan Gambar 7 memeprlihatkan grafik pola perubahan kadar Al terlarut.

Penggunaan elekltroda Al pada anoda akan menghasilkan spesi-spesi kimia kationik seperti $\mathrm{Al}^{3+}$, dan $\mathrm{Al}(\mathrm{OH})^{2+}$ pada $\mathrm{pH}$ rendah, dan pada $\mathrm{pH}$ yang sesuai akan ditrasformasikan menjadi $\mathrm{Al}(\mathrm{OH})_{3}$ dan akhirnya terpolimerisasi menjadi $\mathrm{Al}_{\mathrm{n}}(\mathrm{OH})_{3 \mathrm{n}}$. Namun demikian $\mathrm{pH}$ larutan juga dapat memoengaruhi terbentuknya spesi lain seperti $\mathrm{Al}(\mathrm{OH})^{2+} ; \quad \mathrm{Al}_{2}(\mathrm{OH})_{2}{ }^{4+}$ dan $\mathrm{Al}(\mathrm{OH})^{4+}$ (Mollah et al, 2001).

Pada kondisi $\mathrm{pH}$ yang semakin tinggi, akan terbentuk $\mathrm{Al}\left(\mathrm{H}_{2} \mathrm{O}\right)_{5} \mathrm{OH}-$ yang larut tidak terendapkan sehingga kadar $\mathrm{Al}$ semakin meningkat. Hal ini berbeda dengan sifat ion $\mathrm{Fe}^{3+}$. Ion ini tidak memiliki kecenderunan membentuk kompleks ion, tetapi cenderung berbentuk sebagai $\mathrm{Fe}(\mathrm{OH})_{3}$ yang mengendap ( Weiner, 2000).

Meskipun tidak ditentukan baku mutu $\mathrm{Al}$ untuk air limbah dalam KepmenLH no 5 Tahun 2014, namun perlu diantisipasi meningkatnya Al akibat penerapan voltase yang semakin tinggi. Meningkatnya kadar Al dalam air akan menyebabkan kekeruhan meningkat, selain dari itu akan terjadi pemborosan eletroda. Oleh karena itu diperlukan penerapan voltase yang optimum untuk mendapatkan efisiensi dan efektifitas pengolahan air limbah. 
Memperhatikan kadar Al terlarut yang semakin meningkat, maka voltase optimum adalah 15 volt dengan waktu elektrokoagulasi 45 sampai 60 menit.

Tabel 6. Hasil rata-rata analisis Al terlarut $(\mathrm{mg} / \mathrm{L})$ pada berbagai waktu kontak

\begin{tabular}{|c|c|c|c|c|c|c|}
\hline \multirow{2}{*}{$\begin{array}{l}\text { Voltase } \\
\text { (volt) }\end{array}$} & \multirow{2}{*}{$\begin{array}{c}\text { Kerapatan Voltase } \\
\text { (volt/cm) }\end{array}$} & \multicolumn{5}{|c|}{ Rata-rata kadar $\mathrm{Al}$ terlarut $(\mathrm{mg} / \mathrm{L})$} \\
\hline & & 0 menit & 15 menit & 30 menit & 45 menit & 60 menit \\
\hline 9 & 1,8 & 0,02 & 0,12 & 0,22 & 0,28 & 0,37 \\
\hline 12 & 2,4 & 0,02 & 0,14 & 0,23 & 0,32 & 0,48 \\
\hline 15 & 3,0 & 0,02 & 0,12 & 0,27 & 0,35 & 0,47 \\
\hline 20 & 4,0 & 0,02 & 0,18 & 0,28 & 0,46 & 0,55 \\
\hline \multirow{7}{*}{ 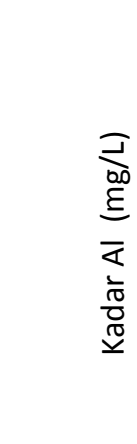 } & 0,6 & & & & \multirow{5}{*}{\multicolumn{2}{|c|}{$\begin{array}{l}-9 \text { volt } \\
-12 \text { volt } \\
-15 \text { volt } \\
* 20 \text { volt }\end{array}$}} \\
\hline & 0,5 & & & & & \\
\hline & 0,4 & & & & & \\
\hline & 0,3 & & & & & \\
\hline & 0,2 & & & & & \\
\hline & 0 & & & & $\neg$ & \\
\hline & 0 & 15 & 30 & 60 & 75 & \\
\hline
\end{tabular}

Gambar 7. Grafik hubungan Kadar Al dengan waktu kontak elektrokoagulasi

\section{KESIMPULAN}

Pengolahan limbah cair industri kosmetik dapat dilakukan dengan metoda elektrokoagulasi dengan jarak antara elektroda aluminium $5 \mathrm{~cm}$. Semakin tinggi voltase yang diterapkan semakin baik penuruan COD dan TSS, namum menaikkan $\mathrm{pH}$ hasil olahan. Kondisi optimum diperoleh pada penerapan voltase 20 volt (kerapan voltase 4 volt $/ \mathrm{cm}$ ) dan waktu elektrokoagulasi selama 45 menit.

Pengolahan terbaik kondisi optimum menghasilkan mutu air : $\mathrm{pH}=9,96 ; \mathrm{DO}=6,9$ $\mathrm{mg} / \mathrm{L} ; \quad \mathrm{COD}=280 \mathrm{mg} / \mathrm{L}$ (penurunan 74,19\%); TSS $=88 \mathrm{mg} / \mathrm{L}$ (penurunan $86,21 \%$ ); $\mathrm{Fe}=0,31 \mathrm{mg} / \mathrm{L}$ (penurunan $\mathrm{Fe}$ 80,38 \%). Hasil pengolahan elektrokoagulasi ini memenuhi baku mutu air limbah menurut Permen LH no 05 tahun 2014 lampiran XLVII golongan II kecuali $\mathrm{pH}(>9,0)$., dan dapat dibuang badan air.

Perlu dilakukan uji pengolahan limbah cair kosmetik skala industri dengan metoda kontinyu dan pengolahan lanjutan. Pengolahan lanjutan dapat dilakukan dengan kolam pengendapan dengan bioindikator ikan dan tanaman air (fitoremediasi). Luas kolam indikator disesuaikan dengan debit air limbah. Kombinasi pengolahan elektrokoagulasi dengan fitoremediasi perlu

dipelajari guna metoda pengolahan yang lebih efektif dan efisien.

\section{UCAPAN TERIMA KASIH}

Ucapan terimakasih disampaikan kepada pihak perusahaan yang telah mendukung penelitian ini dan pihak laboratorium kimia FMIPA Unpak yang telah memfasilitasi peneltian ini.

\section{DAFTAR PUSTAKA}

Alex A. (2015). Municipal Wastewater Treatment By Electrocoagulation. International Journal ofTechnology Enhancements and Emerging Engineering Research. 3(5): 62-65.

Ali E and Zahira Yaakob. (2012). Electrocoagulation for Treatment of Industrial Effluents and Hydrogen Production, Chapter 11. INTECH, pp: 228-242.

http://dx.doi.org/10.5772/48633. 
Bazrafshan E, Hossein M, Ferdos K M, and Shina N. (2013). Application of Electrocoagulation Process for Dairy Wastewater Treatment. Journal of Chemistry: 1-8. Article ID 640139. http://dx.doi.org/10.1155/2013/640139.

Butler E, Yung-T H , Ruth Yu-Li Yeh, M Suleiman Al Ahmad. (2011). Review: Electrocoagulation in Wastewater Treatment. Water, 3. 495-525. doi:10.3390/w3020495.

Chaturvedi S I. (2013). Electrocoagulation: A Novel Waste Water Treatment Method. Internatioanl Journal of Modern Engineering Research (IJMER). 3(1): 93100.

Connel D W \& Gregory J Millder. (1995). Kimia dan Ekotoksikologi Pencemaran. a.b, Yanti Koestoer. Penerbit UI-Press.

Gameissa M W, Suprihatin, Nastiti S I. (2012). Pengolahan tersier Limbah Cair Industri angan Dengan Teknik Elektrokoagulasi Menggunakan Elektroda Stainless Steel. Agro Industri Indonesia, 1(1): 31-37.

Ghalwa N M A, Alaa M S, and Nader B F, (2016). Removal Of Reactive Red 24 Dye by Clean Electrocoagulation Process Using Iron and Aluminum Electrodes. $J$ Chem Eng Process Technol. 7:1. DOI: 10.4172/2157-7048.1000269.

Hanum F, Rondang T, M Yusuf R, William W K. (2015). Aplikasi Elektrokoagulasi dalam Pengolahan Limbah Cair Pabrik Kelapa Sawit. Journal Teknik Kimia USU. 4(4): 13-17.

Harsanti M dan Bambang H P. (2010). Pengolahan Limbah Cair Tekstil Menggunakan Proses Elektrokoagulasi dengan sel Al-Al. Journal Pengembangan Teknologi Kimia untuk Pengolahan Sumber Daya Alam Indonesia: Yogyakarta.
Irawan D, Zaenal A, dan Emma M. (2012). Proses Penurunan zat warna dalam limbah cair industri sarung samarinda dengan metode elektrokoagulasi. Journal riset teknologi industry. 6(11): 31-36.

Manahan S E. (2005). Environmental Chemistry, 6th ed. Lewis Publishers: Boca Raton.

Marriaga N and F M- Martinez. (2014). Fundamentals of electrocoagulation, in Evaluation of Electrochemical Reactors as a New Way to Environmental Protection: Reasearch Signpost, Kerala, India: 1-16.

Mollah, M.Y.A, Pathak, S. R., Patil, P.K., Vayuvegula, M., Agrawal, T.S., Gomes, J.A.G., Kesmez, and Cocke, D. Dl. (2004). Treatment of orange II Azo dye by electrocoagulation (EC) technique in a continuous flow cell using sacrifical iron electrode, J. Hazard. Mater., B109. 165171.

Setianingrum N Pi, Agus $\mathrm{P}$, dan Sarto. (2017). Pengurangan Zat Warna Remazol Red Rb Mrenguunakan Metode Elektrokoagulasi secara Batch. Jurnal Rekayasa Proses. 11(2): 78-85.

Trianggono, Retno I dan Fatma L. (2007). Buku Pegangan Ilmu Pengetahuan Kosmetik. PT Gramedia Pustaka Utama: Jakarta.

Vepsäläinen M. (2012). Electrocoagulation in the treatment of industrial waters and wastewaters. JULKAISIJA UTGIVARE - PUBLISHER, Kopijyvä Oy, Kuopio.

Weiner E R. (2000). Application of environmental chemistry: a practical guide for environmetal professional. CRC Press, Lewis publisher, Boca Raton.

Yousuf M A M, Robert S, Jose R P, David L C. (2001). Electrocoagulation(EC)science and applications. Journal of Hazardous Materials B84 : 29-41. 